\title{
NORFACE
}

MIGRATION

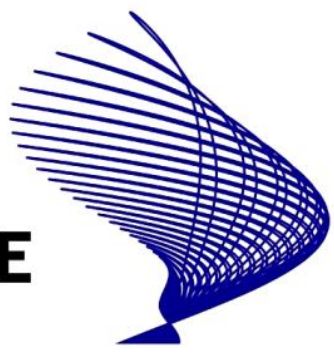

\section{Dynamics of Educational Differences in Emigration from Estonia to the Old EU Member States}

Kristi Anniste, Tiit Tammaru, Enel Pungas and Tiiu Paas 


\title{
Dynamics of Educational Differences in Emigration from
}

\section{Estonia to the Old EU Member States}

\author{
Kristi Anniste ${ }^{\#} *, \$$ (kristi.anniste@gmail.com) \\ Tiit Tammaru* (tiit.tammaru@ut.ee) \\ Enel Pungas* (enel.pungas@ut.ee) \\ Tiiu Paas" (tiiu.paas@ ut.ee) \\ * Department of Geography, University of Tartu \\ Vanemuise 46, Tartu 51014, Estonia \\ \# Faculty of Economics, University of Tartu \\ Narva mnt 4, Tartu 51009, Estonia
}

$\S$ Corresponding author.

Acknowledgement. This research was supported by the NORFACE research programme on Migration in Europe-Social, Economic, Cultural and Policy Dynamics (MIDI-REDIE). The authors are also thankful for the financial support of the European Social Fund, Estonian Ministry of Education and Science (target financed research project no. SF0180052s07), Estonian Science Foundation (grant no. 8774). 


\title{
Dynamics of Educational Differences in Emigration from Estonia to the Old EU Member States
}

\author{
Kristi Anniste, Enel Pungas, Tiit Tammaru, Tiiu Paas
}

\begin{abstract}
The study analyzes the changes in emigration from Estonia in order to shed more light on East-West migration, contributing to the main debate on "brain drain" by focusing on educational differences in emigration. We use anonymous individual level data for all emigrants from the register-based Estonian Emigration Database compiled by Statistics Estonia for the period 2000-2008. The analysis shows that there has been no significant brain drain from Estonia as the new EU member state during this period. Moreover, we find evidence of a spreading of the emigration norm into a wider range of population groups, including the less educated, since Estonia joined the European Union in 2004.
\end{abstract}

Key words: education; emigration; East-West migration; Estonia 


\section{Introduction}

East-West migration developed into a mass phenomenon in Europe at the end of the 1980s, around the time of the fall of the Berlin Wall in 1989 and prior to the collapse of the Soviet Union in 1991 (Mansoor and Quillin 2007; Massey and Taylor 2004; Okólski 2004). Emigration from central and eastern European countries accelerated after the enlargement of the European Union (EU) in 2004 and 2007 (Kahanec et al. 2010). Differences in wealth levels between eastern and western Europe, and improved access to the labour markets of the old member states (EU-15) for the citizens of central and eastern European (CEE) countries are considered to be the most important catalysts for migration within Europe, bringing along "brain drain" in origin countries, and "brain gain" in receiving countries as a result of the migration of the skilled (Castels and Miller 2009; Bonifazi et al. 2008; Favell 2008). There are different conceptualizations for the skilled migrants, but the most common and accessible approach is to study people with university education (Gibson and McKenzie 2011a; 2011b).

Whereas the majority of East-West migration research in Europe has focused on the effects of emigration on the origin and destination countries and their labour markets, less is known about the composition of migrant populations, and especially how it has changed over the time. The aim of this study is to clarify changes in the level of education of Estonian emigrants before and after EU enlargement. Emigration barriers are usually lower for higher educated, and EU enlargement reduced such barriers significantly. This makes the topic of changes in the educational composition of migrants in the context of East-West migration in Europe especially relevant. Estonian case is interesting for two reasons for studying the relationship between emigration and education. First, Estonia has experienced significant emigration since 1991 as most other countries of eastern Europe (Tammaru et al. 2010). Second, Estonia is economically relatively well performing compared to many other new EU member states. In order to shed new light on educational differences in East-West migration, our study of Estonian emigration seeks answers to two main research questions:

- Are people with a university degree over-represented among emigrants from Estonia?

- Are people with lower levels of education increasing their share among emigrants from Estonia after it joined the EU in 2004?

Data for the study comes from the Estonian Emigration Database compiled by Statistics Estonia. One of the problems in studies of East-West migration in Europe relates to the poor data quality, especially the fact that people leaving abroad do not deregister themselves in the country of origin (de Beer et al. 2010). Such under-registration of emigration is also a problem in Estonia (Anniste 2009). But Estonian data has some properties that improve its reliability despite the fact that not all migrants register when they leave the country. Most important is the fact that population registers in Estonia and 
Finland exchange information on a regular basis. Finland is the main destination country of Estonian emigrants. Data exchange with Finland has thus significantly improved the quality of emigration statistics in Estonia - all people who settle permanently in Finland get an emigrant status in the Population Register of Estonia (Anniste 2009). The Estonian data thus allows us to shed new light on the nature of the changes that have occurred in East-West migration in Europe since 2000.

\section{Review of the literatuure on education and East-West migration in Europe}

Differences in wealth levels, the removal of restrictions on free movement of labour, reduced costs for transportation and communications (including the expansion of budget airlines), the expansion of formal and informal labour recruitment networks, and initiatives by governments and employers to recruit labour into specific economic sectors have resulted in an increase in and diversification of international migrant flows in Europe (Moriarty 2011; Salt 2008; Massey and Taylor 2004; Okólski 2004). The large scale emigration has become one of the biggest concerns both in Estonia and in CEE countries in general (Estonian Human Development Report 2011; Kahanec et al. 2010). There is also a lack of knowledge about the exact composition of migrants, and how it has changed over time. For example, it is not well documented which population groups benefit the most from free labour market policies. Less than adequate knowledge about the extent and dynamics of emigration has led to migration-related fears in both European origin and destination countries. In origin countries, the major fear relates to losing of the highly educated (Guth and Gill 2009; Favell 2008). In destination countries, the major fear relates to the downward pressure on wages as a result of an inflow of cheap labour from Eastern Europe (Krings 2009; Borjas 2003; Boeri and Brücker 2001). In order to study the effects of migration in the countries involved, we need to know more about the educational composition of migrants.

Previous research reveals that migrants from CEE countries are generally well-educated (Olofsson and Malmberg 2010; Krišjāne et al. 2009; Kępińska 2007). For example, in both Latvia and Poland, the proportion of emigrants who have a university education is higher than in the overall population of those countries. The study by Olofsson and Malmberg (2010) also shows that 43 percent of the immigrants from the former Soviet republics (except the three Baltic countries of Estonia, Latvia and Lithuania) to Sweden have at least a Bachelor's degree. The emigration of the better educated is explained by the need for highly educated professionals in western Europe, for instance, in sectors such as medicine and information and communication technology. Borjas (1999) and Dumont et al. (2005) suggest that the increasing demand for highly educated workers is common throughout the world, resulting in an inflow of this category of migrants also 
from eastern to western Europe. Highly educated people have more social capital, better language skills, and access to information, and they have more resources to finance a move, which makes them more mobile (Gugushvili 2011; Poot et al., 2008). It should be noted, however, that the majority of East-West migrants do low-waged jobs in the service and manufacturing sectors in western Europe (Ciupijus 2011; Cook et al. 2010; Pollard et al. 2008).

There are no studies based on large scale national micro data that explicitly focus on changes in the educational composition of emigrants before and after EU accession among the new EU member states. Since the barriers for migration from eastern to western Europe have changed significantly in the course of time, changes in emigration by education can be expected as well. The mechanism could be as follows. Although emigration from eastern Europe eased significantly after the fall of the Berlin Wall and disintegration of the Soviet Union, the right to move within Europe was separated from the right to work in the 1990s (Ciupijus 2011). The gradual opening of the labour market of the old EU member states to the people living in the new EU member states has thus been a very important step in removing restrictions from the free movement of labour within EU. Since higher migration barriers generally work against more disadvantaged population groups, including people with lower levels of education, lowering of such barriers could facilitate their mobility relative to people with higher levels of education (cf. Gugushvili 2011). Therefore the research question ,are people with lower levels of education increasing their share among emigrants from Estonia after it joined the EU in 2004?" is particularly relevant in order to fill the research about changes in educational composition of emigrants after EU eastward enlargement.

\section{Main features of emigration from Estonia since 1991.}

Estonia was a country of immigration during the Soviet period, but similarly to many other CEE countries it became a country of emigration after regaining its independence in 1991 (Statistics Estonia 2011; Tammaru and Kulu 2003; Katus and Sakkeus 1993) (Figure 1). Emigration took the form of return migration of Russians back to Russia in the 1990s, and emigration to western Europe was modest at that time. From the very beginning of the 1990s, the neighboring country Finland became the main destination country for westward migration from Estonia. Emigration from Estonia to the old EU member states increased in the 2000s compared to the 1990s. But the main destination country, Finland, has remained the same. Being both geographically and linguistically close to Estonia, it is the most attractive choice for Estonian emigrants. As very few immigrants from other CEE countries move to this country, Estonians have become the largest new immigrant group in Finland (Statistics Finland 2011). 


\section{FIGURE 1 ABOUT HERE}

But some important changes in emigration took place during the 2000s as well. Data from EED reveals that there was a continued increase in the number of emigrants in 2000-2004, followed by a rapid growth in emigration in 2005 or immediately after Estonia joined the EU (Figure 2). After EU enlargement in 2004, the old EU member states (EU-15 countries) became increasingly attractive destinations for emigrants from all new member states (Krišjāne et al. 2009; Thaut 2009; Kępińska 2007; Fihel et al. 2006). Estonia was no exception in this respect. For example, emigration from Estonia to Ireland and the UK increased more than eightfold and emigration to Finland increased more than fivefold from 2000 to 2008, whereas emigration to the US and Canada decreased by 1.8 and 2.5 times, respectively (Figure 3 ).

FIGURE 2 ABOUT HERE

FIGURE 3 ABOUT HERE

\section{Research data}

Data for the current study comes from Statistics Estonia. The raw data is stored in the Estonian Population Register, but Statistics Estonia cleans the data and completes the database with information from other sources, such as the Citizenship and Migration Board. We use anonymous individual-level extraction of all emigrants from Estonia between 2000 and 2008, and we refer to this data as the Estonian Emigration Database (EED). Let it be noted that the database contains only permanent migrants, e.g. the migrants who did not return to Estonia within one year after emigration. The EED provides information on 29,377 individuals. We restrict our research population to emigrants who 1) were aged 20 or over at the time of emigration, and 2) left Estonia to EU-15 countries in 2000-2008, i.e. to 19,018 individuals. This data allows us to compare changes in the origins, destinations, and composition of the migrant population over time. The EED contains the date of migration, last place of residence in Estonia at municipal level, country of destination, gender, age, ethnicity, and level of education. Knowing the last municipality of residence allows us to construct several place-specific variables, such as local level of unemployment. Municipalities are quite small in Estonia, with an average population size of 5,905 inhabitants. Therefore, municipality-level variables depict the immediate living environment fairly accurately.

We are aware that data in the EED are not without shortcomings. First, although EastWest migration from Estonia started in the 1990s, the EED allows us to analyze 
migration only from 2000 onwards. From the data quality perspective it is good, however. When Estonia left the Soviet Union in 1991, the strict Soviet-era system of registration of places of residence ended and it was not immediately replaced with a new system. Instead, registering one's place of residence became voluntary (Sjöberg and Tammaru 1999). This swing of the bureaucratic pendulum from one extreme to the other was in line with the neoliberal atmosphere that spread across CEE countries at the beginning of the 1990s (Bockman and Eyal 2002); a reaction to living in a highly controlled society in the formerly centrally planned countries in Europe. The collection of Estonian migration data became more systematic again when a law regulating registration of residence came into force in 2002 (Anniste 2009). Nevertheless, data on emigration is still incomplete, because migrants do not always deregister themselves in Estonia when moving to another country (Herm et al. 2005), a problem that is common in most emigration countries (de Beer et al. 2010). In this context, the harmonization of migration data with destination countries, as between Estonia and Finland, is vital for improving data accuracy.

The second shortcoming of the data relates to the time of emigration. The time when data is entered into the Population Register does not necessarily reflect the time when emigration actually takes place (Herm et al. 2005). An individual can report departure to a foreign country while still in Estonia or when already in the destination country. It is therefore often difficult to define the exact moment of the move. For example, some intervening moves could precede final settlement in a new country. Alternatively, people might intend to move to another country temporarily, but could later decide to migrate permanently, for instance, if they find a partner or suitable job that ties them to that country. The higher share of circular migration in East-West migration in Europe compared to global South-North migration (Castles and Miller 2009) makes it even more complicated to measure the exact timing of the migration events. It is very typical that the date of actual migration takes place before the date of registration of the move. For example, many people register their move only when they renew or change documents, legalize their work or start to school their children. This need to make eventual contact with the authorities in their new homelands helps to mitigate against the problem of under-registration of moves.

The third shortcoming relates to the fact that data on the level of education is incomplete in the Estonian Population Register (and other Estonian registers). This carries on to EED, where 20 percent of emigrants have missing values for their level education. Unfortunately, there is no analysis of the reasons for these missing values. But at the broadest level, there are three main possible explanations for why people do not have a specified level of education in Estonian registers. First, the nowadays formally accepted level of education is not fully clear for many people who completed their education 
during the Soviet period since the education variable has been filled in retrospectively. As the level of education of the Estonian population has increased considerably since the Soviet period (Paulus 2004) there is a strong reason to expect that less educated rather than better educated are over-represented among people with missing values for education. Today, Estonia has an operating education register that is linked to the Population Register and the level of education is covered for younger generations who have completed their studies. But among younger people there is a problem that not all of them have finished their educational career. That could be the second reason for missing values for the level of education. The third source of missing values could be related to school dropouts. This has been an important problem in Estonia during the last two decades. For example, there are about 1 percent of pupil dropouts annually between grades 7-9 in Estonia (Mündi 2006). Whatever is the exact distribution of these three causes of missing values in EED, there is certainly no reason to expect that the university-educated are overrepresented in this category of people. Despite such qualityrelated concerns, the individual-level EED database still enables us to shed new light on East-West migration in Europe, especially since Estonia enjoys data exchange with its main destination country Finland.

\section{Descriptive analysis: emigration from Estonia since 2000}

We start our empirical analysis by comparing the characteristics of emigrants, in particular their level of education, with those of the total population living in Estonia at the time of the 2000 census date. The 2000 census still provides the most comprehensive picture about the composition of the Estonian population. Since data in EED start from the 2000 census, the year 2000 is also an appropriate reference for studying the selectivity of emigration in the 2000s. It appears that in comparison with the total population, migrants are significantly younger and somewhat less educated (Table 1). The proportion of emigrants who are lower-educated is bigger in 2004-2008 compared to 2000-2003 (Table 1). EED also clearly shows that the proportion of university-educated people in the emigrant population is much less than in the total Estonian population and that the proportion of emigrants who are highly educated has further decreased since Estonia joined the $\mathrm{EU}^{3}$. A closer look at the emigration dynamics by education in the 2000s reveals that the percentage of migrants with a lower than university-level education increased significantly just after Estonia joined the EU in 2004.

TABLE 1 ABOUT HERE

FIGURE 4 ABOUT HERE 


\section{Specification of logistic regression models}

We proceed by applying a series of logistic regression models to the EED data in order to clarify the changes in the composition of emigrants from Estonia to the old EU member states (EU-15 countries) before and after joining the EU in 2004. The main focus of the data analysis is on changes in the educational composition of the Estonian emigrants since EU eastward enlargement in 2004. We are interested whether the results obtained in the previous section remain in a multivariate research setting. The full regression model can be written as follows:

$$
\log \frac{p\left(Y_{i}=1\right)}{1-p\left(Y_{i}=1\right)}=\alpha+\sum_{\mathrm{k}=1}^{\mathrm{k}} \beta_{k} X_{i k}
$$

where

- $p\left(Y_{i}=1\right)$ is an individual's $i=1, \ldots I$ probability of migrating from Estonia to the EU-15 member states between 2004 and 2008;

- $1-p\left(Y_{i}=1\right)$ is an individual's $i=1, \ldots I$ probability of migrating from Estonia to the EU-15 member states between 2000 and 2003;

- $\alpha$ is a constant; $X_{i k}$ is the value of the variable for an individual;

- $\beta_{k}$ is the parameter that describes the effect of this variable, with $\mathrm{K}$ variables.

We estimate three regression equations, adding new control variables step-wise into the models. Model 1 includes only level of education, because this is the variable of main interest for this study. In Model 2, we add other personal variables, origin municipality, and destination country characteristics in order to control for whether the initial relationship between education and post-EU enlargement migration found in the baseline model is affected by other compositional differences between emigrants before and after Estonia joined the EU. In Model 3 we additionally add some interaction variables testing for joint effects of education and ethnicity.

First, we control for the standard personal variables of gender and age. Next, we control for ethnicity since Estonia is a country with a high share of ethnic minority population (one third of the total population). Table 1 in this paper and also some previous studies showed that ethnic composition in emigration vary over time (Hughes 2005). We also control for variables of place of origin in our regression models. In the 2000s, international mobility has become an important alternative for rural emigration. Since the labour market opportunities are worse and the share of better educated people is smaller in rural areas compared to urban areas (Statistics Estonia 2011) we control for the 
rural/urban residence in our regression models. Then we introduce the destination country (Finland/Otherwise) into Model 2 in order to control for the possible effects introduced by the data exchange between Estonian and Finnish Statistical Offices. In Model 3, we finally test for interaction effects.

\section{Results of the logistic regressions based analysis}

Next, we report the results of the logistic regression that compares the composition of emigrants before (2000-2003) and after (2004-2008) Estonia joined the EU. Model 1 includes education only, and it shows that the odds of being lower educated are higher in the post-accession emigration group. After joining the EU, people with primary education have 1.8 times higher odds to be an emigrant than people with secondary education, while people with university education have 0.5 times the odds to be an emigrant compared to people with secondary education (Table 2, Model 1). The results for education are robust and remain unchanged after adding individual-level control variables, variables characterizing places of origin, and destination country variables (Table 2, Model 2). In short, the probability for emigrants to be less educated has increased after EU enlargement.

\section{TABLE 2 ABOUT HERE} FIGURE 5 ABOUT HERE

We briefly discuss also the results for other variables additionally to education variables (Table 2, Model 2). Gender and age differences in emigration before and after EU accession are mainly insignificant, but the odds of being an emigrant are smaller among the oldest (60+) age group since 2004. Emigration has spread down the urban hierarchy, with increased probability of living in the geographically peripheral rural areas of the country during the post-EU accession period. We were also interested whether there is an interaction effect between level of education and place of residence in urban or rural areas before emigration, but were not able to detect it.

The results for other variables are most interesting with respect to ethnicity. The odds of an emigrant being an ethnic Estonian are higher since 2004 compared to the preaccession period. One of the reasons for this change in the ethnic composition of the emigrant population could be related to the high share of Russian minorities who do not have Estonian citizenship. There are around 100,000 residents with undefined citizenship who can travel within the Schengen zone without a visa, but need to apply for a work or residence permit if they wish to stay for more than 90 days, or to work or to study in other EU member states ${ }^{21}$. Therefore, the policies of free movement of labour do not pertain to all the workers of Estonia with ethnic minorities not being able to equally take 
advantage of open labour markets in the EU-15 countries. We also find significant interaction effects between the level of education and ethnicity (Table 2, Model 3). Figure 5 visualizes this effect by showing that since 2004 both lower educated and highly educated Russians have higher odds to emigrate than Russians with secondary education. It seems to suggest that well educated ethnic minorities do not enjoy equally good career opportunities in Estonia as Estonians do, which is in line with the results of the research that shows that a "glass ceiling" effect has emerged for minorities in the Estonian labour market (Lindemann and Saar 2008). This could make some of them pursue their careers abroad. The less educated minorities who suffer from the lowest salaries in the Estonian labour market (Toomet 2011) could, similarly to less educated Estonians, also find better paying labour markets in western Europe much more attractive than Estonia.

\section{Conclusion and discussion}

This study analyzed changes in the level of education of Estonian emigrants in the 2000s with a focus on changes before and after EU accession in 2004, and it provided new insights on the debate on brain-drain in East-West migration. Firstly, an overall increase in emigration has taken place after Estonia joined the EU in 2004. This is similar to EastWest migration in general (Kahanec et al. 2010; Castles and Miller 2009; Favell 2008). Secondly, the proportion of university-educated people in the emigrant population is much less than in the total Estonian population before and after Estonia joined the EU. This is different from many other countries involved in the East-West migration in Europe, including the territories of the former Soviet Union (Olofsson and Malmberg 2010; Krišjāne et al. 2009; Kępińska 2007). And thirdly and most importantly, the share of the university-educated has decreased over time among Estonian emigrants. We further find that the increase of emigration in the 2000s was also due to the growing number of rural inhabitants among emigrants.

EU accession and the parallel global economic boom that took place in the middle of the 2000s are probably the most important factors that shaped changes in Estonian emigration during our study period in 2000-2008. First, a significant increase in emigration occurred after 2004 when Estonia joined the EU. While emigration to Finland has been an important feature of Estonian emigration throughout the 2000s, leaving for more distant countries, especially to the UK, increased significantly after EU accession. Similar growth in emigration and the increased attraction of the UK has been observed in other countries that joined the EU in 2004 (Castles and Miller 2009; Drinkwater et al. 2009). People face several obstacles when they wish to emigrate to another country and the barriers are, in relative terms, higher for lower educated and other disadvantaged people (Gugushvili 2011). Although migration from eastern to western Europe eased 
significantly after the fall of the Berlin Wall and the disintegration of the Soviet Union, the right to move within Europe was separated from the right to work (Ciupijus 2011). EU accession and opening of the labour markets have thus been the final steps removing restrictions from the free movement of labour within the EU. The results of our research suggest that, in relative terms, these events were more important for more disadvantaged workers in the labour market such as the lower educated and rural inhabitants and consequently, the emigration norm has spread into those population groups as well. The parallel development of budget airlines in Europe further lowered the barriers for emigration for those with less economic resources (Moriarty 2011).

To sum up, there is no considerable brain drain taking place from Estonia as the new member state of the EU. This finding coincides with the research results of Hazans and Philips (2010), who found that brain drain was not a feature of post-accession Baltic migration. But this study provides also evidence that the share of the university-educated people has decreased among emigrants during the 2000s. These findings call for further cross-national studies that focus more explicitly on the effect of origin country on the education level of emigrants, and to present more evidence on emigration trends by education over time. Future research should therefore attempt to clarify (1) whether the similar spreading of emigration norm to lower educated is common in eastern Europe, (2) whether the eastern European countries with worse macroeconomic environment than Estonia's experience a greater proportion of emigration among highly educated people, and (3) whether the eastern European countries with better macroeconomic environments provided better career opportunities for their highly qualified residents, thus reducing their propensity to emigrate. If the latter is true, it would have an important policy implication, i.e. supporting reform processes in origin countries would be an important mean for reducing emigration of the highly skilled from CEE countries. Another hypothesis that warrants investigation is that the size of the economy has an effect on the level of migration of highly educated people. Countries with small population sizes such as Estonia and the other Baltic countries of Latvia and Lithuania need proportionally more highly educated civil servants and other professionals and working in such an environment may provide such individuals with more challenges and opportunities. It might therefore be that well-qualified people in such countries might decide to stay and work in their own country despite the availability of higher salaries abroad. 
Notes

1 Estonian Ministry of the Interior. Available at: http://www.siseministeerium.ee/ siseministeerium-kutsub-maaratlemata-kodakondsusega-inimesi-eesti-kodakondsusttaotlema/?highlight=kodakondsuseta (last accessed 30 September 2011).

2 As discussed in the "Research Data" section, there are no reasons to believe that university educated are over-represented in the category of people with missing level of education. 


\section{REFERENCES}

Anniste, K. (2009) 'External migration of Estonia,' in Tammaru, T. \& Tammur, A. (eds) (2009) Migration (Statistics Estonia), pp. 60-66.

Bahna, M. (2008) 'Predictions of migration from the new member states after their accession into the European Union: Success and failures,' International Migration Review, 42, 4, pp. 844-860.

Bockman, J. \& Eyal, G. (2002) 'East Europe as a labouratory for economic knowledge: The transnational roots of neoliberalism,' American Journal of Sociology, 108, pp. 310-352.

Boeri, T. \& Brücker, H. (2001) Eastern Enlargement and EU-Labour Markets: Perceptions, Challenges and Opportunities, Discussion Paper, No. 256, February 2001 (IZA).

Bonifazi, C., Okólski, M., Schoorl, J. \& Simon, P. (2008) 'Introduction,' in Bonifazi, C. et al. (eds) (2008) International Migration in Europe. New Trends and New Methods of Analysis (IMSCOE Research, Amsterdam University Press), pp. 9-16.

Borjas, G. J. (1999) Economic Research on the Determinants of Immigration. Lessons for the European Union, Technical Papers 438, (World Bank).

Borjas, G. J. (2003) 'The labour demand curve is downward sloping: Reexamining the impact of immigration on the labour market,' The Quarterly Journal of Economics, 118,4 , pp. $1335-1374$.

Castles, S. \& Miller, M. J. (2009) The Age of Migration. Fourth Edition (London: Palgrave Macmillan).

Ciupijus, Z. (2011) 'Mobile central eastern Europeans in Britain: successful European Union citizens and disadvantaged labour migrants?' Work, Employment and Society, 25, 3, pp. 540-550.

Cook, J., Dwyer, P. \& Waite, L. (2010) 'The experiences of accession 8 migrants in England: Motivations, work and agency,' International Migration, Early View, Published Online: 15 Jan 2010.

de Beer, J., Raymer, J., Van der Erf, R. \& Van Wissen, L. (2010) 'Overcoming the problems of inconsistent international migration data: A New Method Applied to Flows in Europe,' European Journal of Population, 26, pp. 459-481.

Dumont, J.-C. \& Lemaitre, G. (2005) Counting Immigrants and Expatriates in OECD Countries: A New Perspective, Working Paper DELSA/ELSA/WD/SEM(2005)4 (OECD), electronically available at http://www.oecd.org/dataoecd/34/59/35043046.pdf, last accessed 28 September 2011.

Drinkwater, S., Eade, J. \& Garapich, M. (2009) 'Poles apart? EU enlargement and the labour market outcomes of immigrants in the United Kingdom,' International Migration, 47, 1, pp. 161-190. 
Estonian Human Development Report 2010/2011 (2011) Electronically available at http://www.kogu.ee/public/eia2011/eia_eng_2011.pdf, last accessed 28 September 2011.

Eurostat 2012. Real GDP growth rate in European countries. Available at: http://epp.eurostat.ec.europa.eu/tgm/table.do?tab=table\&init=1 \&plugin $=1 \&$ language $=$ en \&pcode $=$ tsieb020 $($ last accessed 30 January 2012)

Favell, A. (2008) 'The new face of East-West migration in Europe,' Journal of Ethnic and Migration Studies, 34, 5, pp. 701-716.

Fihel, A., Kaczmarczyk, P. \& Okólski, M. (2006) Labour Mobility in the Enlarged European Union: International Migration from the EU8 Countries, Working Paper 14/72 (Centre of Migration Research, Warsaw University).

Gibson, J., McKenzie, D. (2011a) 'The microeconomic determinants of emigration and return migration of the best and brightest: Evidence from the Pacific,' Journal of Development Economics, 95, 1, pp 18-29.

Gibson, J., McKenzie, D. (2011b) 'Eight questions of brain drain,' Journal of Economic Perspectives, 25, 3, pp 107-128.

Gugushvili, A. (2011) 'Social stratification, welfare state and emigration intentions,' in Social Relations in Turbulent Times. Geneva, September 7-10 2011 (Geneva, ESA 2011).

Guth, J. \& Gill, B. (2009) 'Motivations in East-West doctoral mobility: Revisiting the question of brain drain,' Journal of Ethnic and Migration Studies, 34, 5, pp. 825841.

Hazans, M. \& Philips, K. (2010) 'The post-enlargement migration experience in the Baltic labour markets,' in Kahanec, M. \& Zimmermann, K. F. (eds) (2010) EU Labour Markets after Post-Enlargement Migration (Springer-Verlag New York, LLC), pp. 255-304.

Herm, A., Jõeveer, J., Senipalu, R. \& Valgma, Ü. (2005) Välisränne. Rahvusvahelise rände andmete metoodika: andmekogumine haldusandmestikest (Statistics Estonia), electronically available at: www.stat.ee/dokumendid/19461, last accessed 10 January 2012.

Hughes, J. (2005) ''Exit' in Deeply Divided Societies: Regimes of Discrimination in Estonia and Latvia and the Potential for Russophone Migration,' Journal of Common Market Studies, 43, 4, pp. 739-762.

Kahanec, M., Zaiceva, A. \& Zimmermann, K. F. (2010) 'EU labour markets after postenlargement migration', in Kahanec, M. \& Zimmermann, K. F. (eds) (2010) EU Labour Markets after Post-Enlargement Migration (Springer-Verlag New York, LLC), pp. 3-45.

Katus, K. \& Sakkeus, L. (1993) Foreign-Born Population in Estonia. Tallinn, EKDK. 
Kępińska, E. (2007) Recent Trends in International Migration, The 2007 SOPEMI Report for Poland, Working Paper No. 29/87 (Centre of Migration Research, Warsaw University).

Krings, T. (2009) 'A Race to the bottom? Trade unions, EU enlargement and the free movement of labour,' European Journal of Industrial Relations, 15, pp. 49-69.

Krišjāne , Z., Bērziņš, M. \& Bauls, A. (2009) 'New labour migration trends: Evidence from Latvia', Geographical Review of Japan, Series B 81, 1, pp. 34-46.

Lindemann, K. \& Saar, S. (2008) 'Non-Estonians in the labour market,' in Vihalemm, T. (ed.) Estonian Human Development Report (Tallinn: Eesti Ekspressi Kirjastuse AS), pp. 95-99.

Mansoor, A. \& Quillin, B. (eds) (2007) Migration and Remittances. Eastern Europe and the Former Soviet Union (Washington DC: The World Bank).

Massey, D. S. \& Taylor, J. E. (2004) 'Introduction,' in Massey, D. S. \& Taylor, J. E. (eds) (2004) International Migration. Prospects and Policies in a Global Market (Oxford University Press), pp. 1-12.

Moriarty, E. (2011) 'From migration to mobility: Polish nationals in the Irish labour market,' in Social Relations in Turbulent Times. Geneva, September 7-10 2011 (Geneva, ESA 2011).

Mündi, Š. (2006) Põhikoolist väljalangenud ja lõpetanud õpilaste riskikäitumine, haigestumine, sotsiaal-majanduslik taust ja toimetulek koolis. MSc dissertation, University of Tartu.

Okólski, M. (2004) 'The effects of political and economic transition on international migration in central and eastern Europe,' in Massey, D. S. \& Taylor, J. E. (eds) (2004) International Migration. Prospects and Policies in a Global Market (Oxford University Press), pp. 35-58.

Olofsson, J. \& Malmberg, G. (2010) 'When will the Russians come? On post-Soviet immigration and integration in Sweden,' International Migration, Early View, Published Online: 22 Jan 2010.

Paulus, A. (2004) Hariduslik ebavõrdsus Eestis 1959-2000: keskmine õpiaeg ja hariduse Gini koefitsient [Educational disparities in Estonia in 1959-2000: the average time of studies and the Gini coefficient], Report of the Praxis Center for Political Studies 7/2004, electronically available at http://www.praxis.ee/fileadmin/tarmo/Projektid/Haridus/hariduslikebavordsus1.pdf, last accessed 30 January 2012.

Poot, J., Waldorf, B. \& Van Wissen, L. (2008) 'Migration in a globalized world: A new paradigm' in Poot, J. et al. (eds) Migration and Human Capital (Cheltenham, Edward Elgar Press), pp. 3-28..

Pollard, N., Latorre, M. \& Sriskandarajah, D. (2008) Floodgates or Turnstiles? Post-EU Enlargement Migration Flows to (and from) the UK, Report of the Institute of Public Policy Research, electronically available at 
http://www.ippr.org/members/download.asp?f=\%2Fecomm\%2Ffiles\%2Ffloodgates _or_turnstiles.pdf, last accessed 28 September 2011.

Salt, J. (2008) 'Managing new migrations in Europe: Concept and reality in the ICT sector,' in Bonifazi, C. et al. (eds) (2008) International Migration in Europe. New Trends and New Methods of Analysis (IMSCOE Research, Amsterdam University Press), pp. 19-36.

Sjöberg, Ö. \& Tammaru, T. (1999) 'Transitional statistics: Internal migration patterns and urban growth in post-Soviet Estonia,' Europe-Asia Studies, 51, 5, pp. 821-842.

Statistics Estonia (2011) Online Population Database. Electronically available at http://pub.stat.ee/px-web.2001/Database/Rahvastik/databasetree.asp, last accessed 05 October 2011.

Statistics Finland (2011) Taskutieto 2011 Väestorekisterikeskus. Electronically available at http://www.vrk.fi/default.aspx?id=102, last accessed 05 October 2011.

Tammaru, T., Kumer-Haukanõmm, K. \& Anniste, K. (2010) 'The formation and development of the Estonian Diaspora,' Journal of Ethnic and Migration Studies, 36, 7, pp. 1157-1174.

Tammaru, T. \& Kulu, H. (2003) 'The ethnic minorities of Estonia: Changing size, location, and composition,' Eurasian Geography and Economics, 44, 2, pp. 105120.

Thaut, L. (2009) 'EU integration and emigration consequences: The case of Lithuania,' International Migration, 47, 1, pp. 191-233.

Toomet, O.-S. (2011) 'Learn English, not the local language! Ethnic Russians in the Baltic States,' American Economic Review, 101, 3, pp. 526-531. 


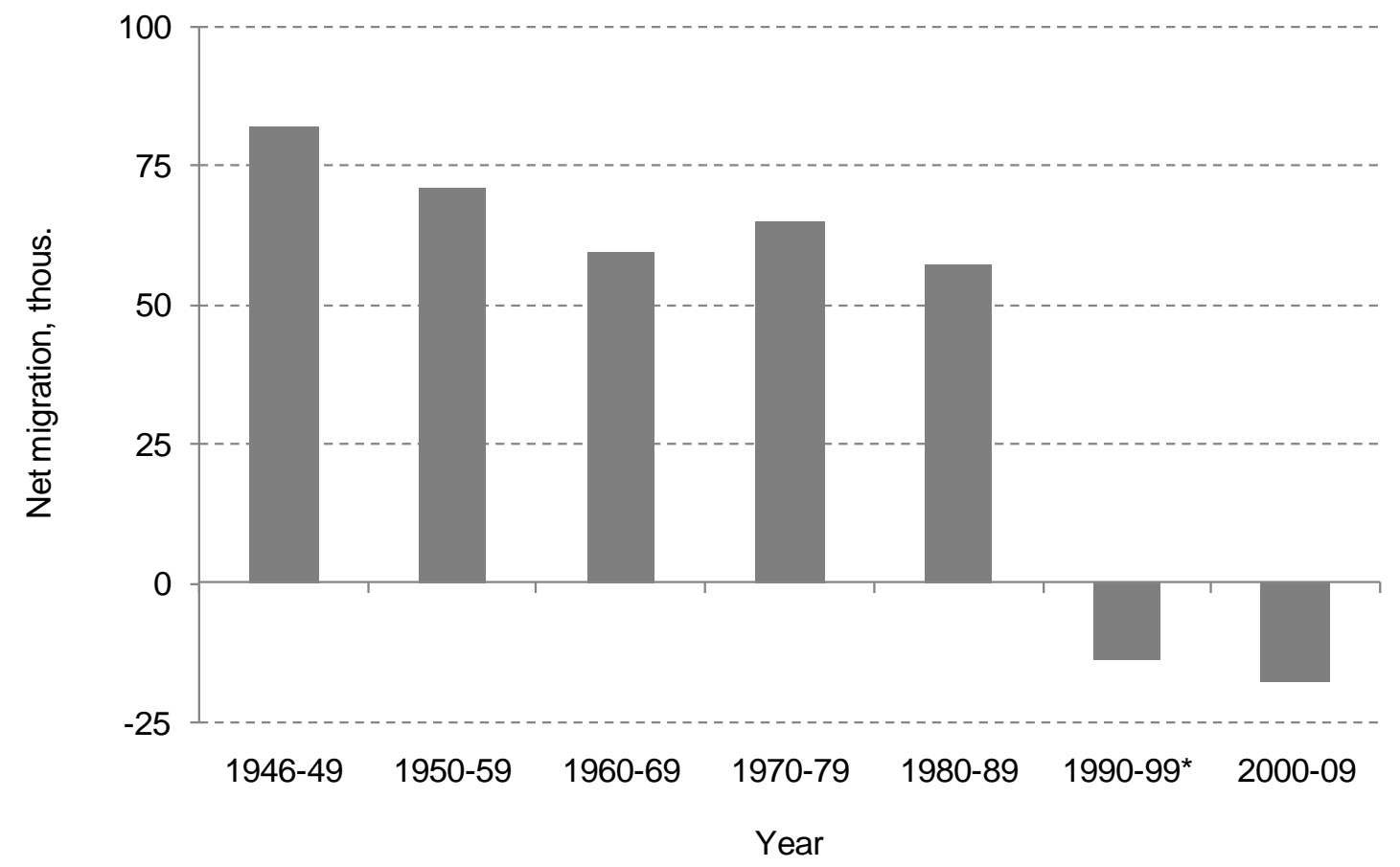

Figure 1. Net migration in Estonia, 1946-2009.

* Without the return migration of the Russian-speaking minority population from Estonia to their homelands that took place during the very beginning of the 1990s, after Estonia regained its independence.

Sources: Katus and Sakkeus 1993; Tammaru and Kulu 2003; Statistics Estonia 2011. 


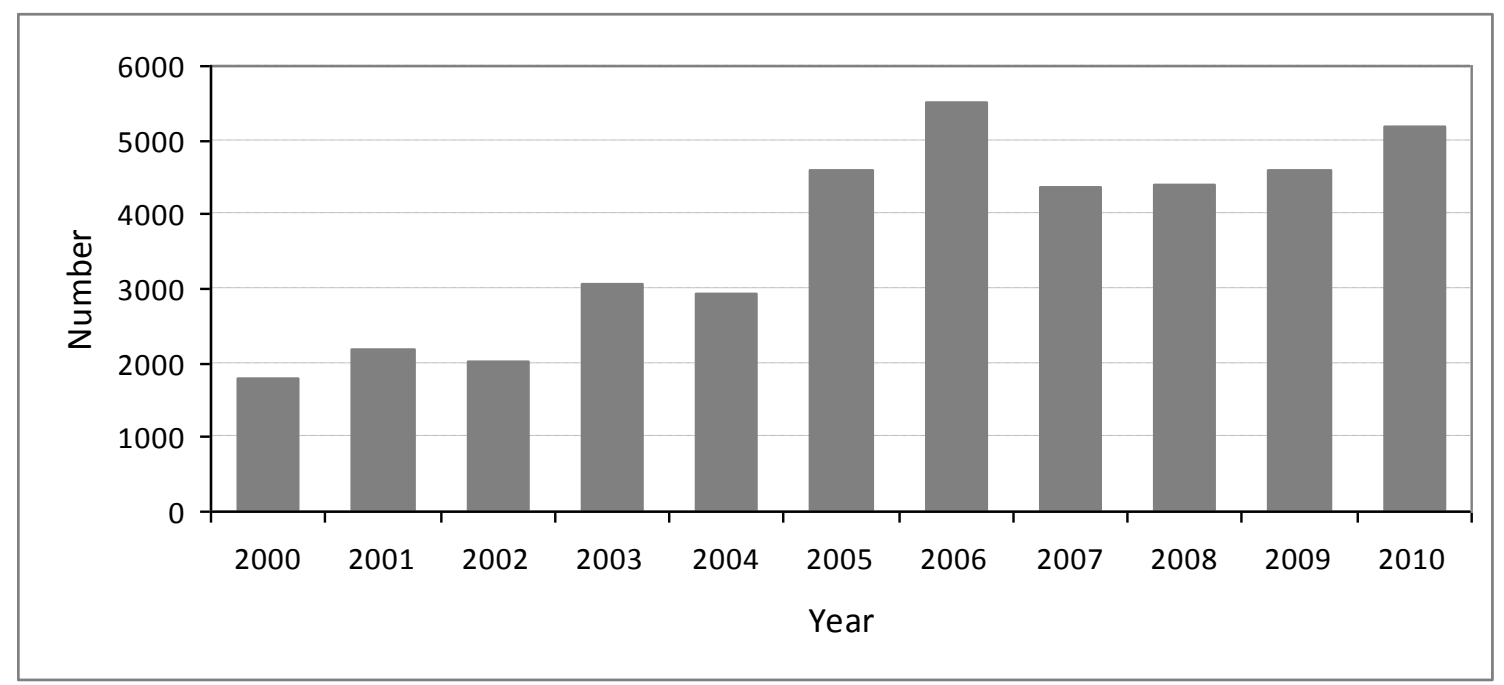

Figure 2. Emigration from Estonia, 2000-2010.

Sources: Statistics Estonia 2011. 


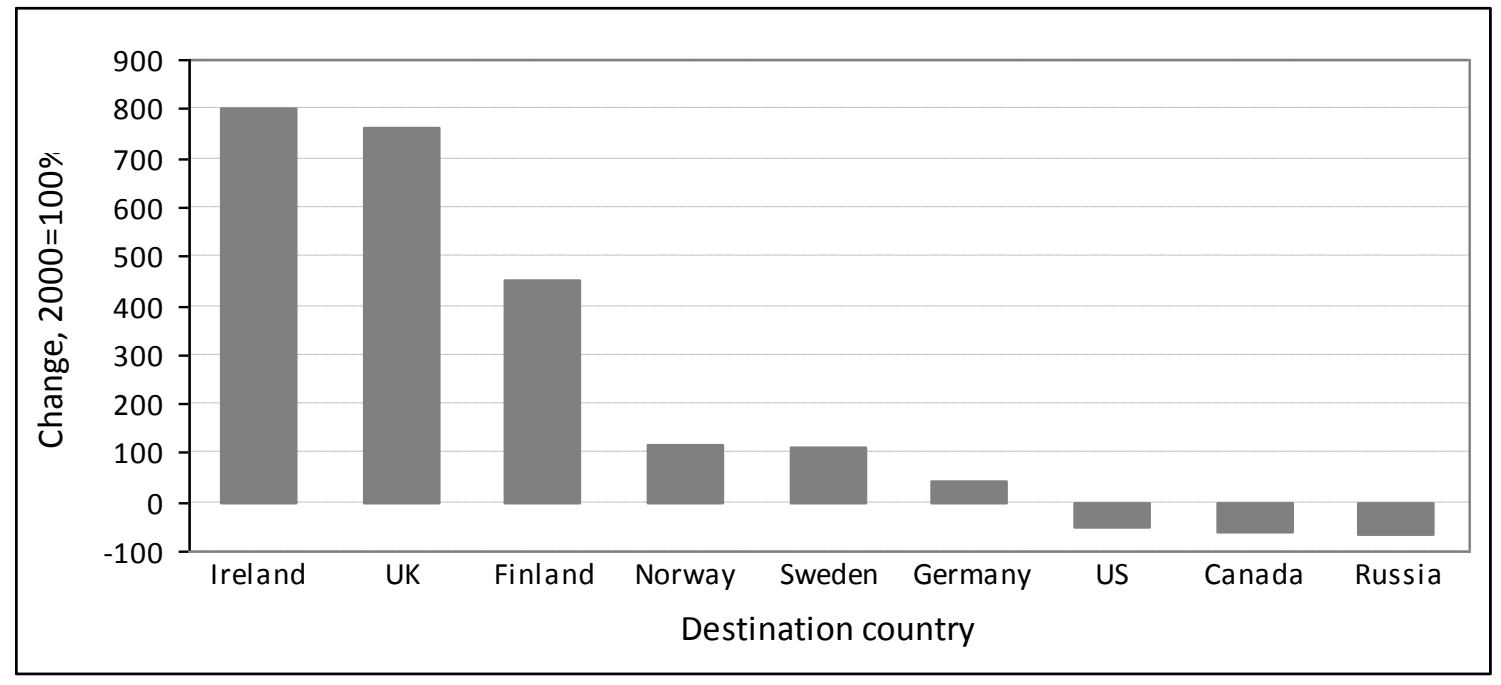

Figure 3. Change in emigration destinations between 2000 and 2008.

Source: EED. 


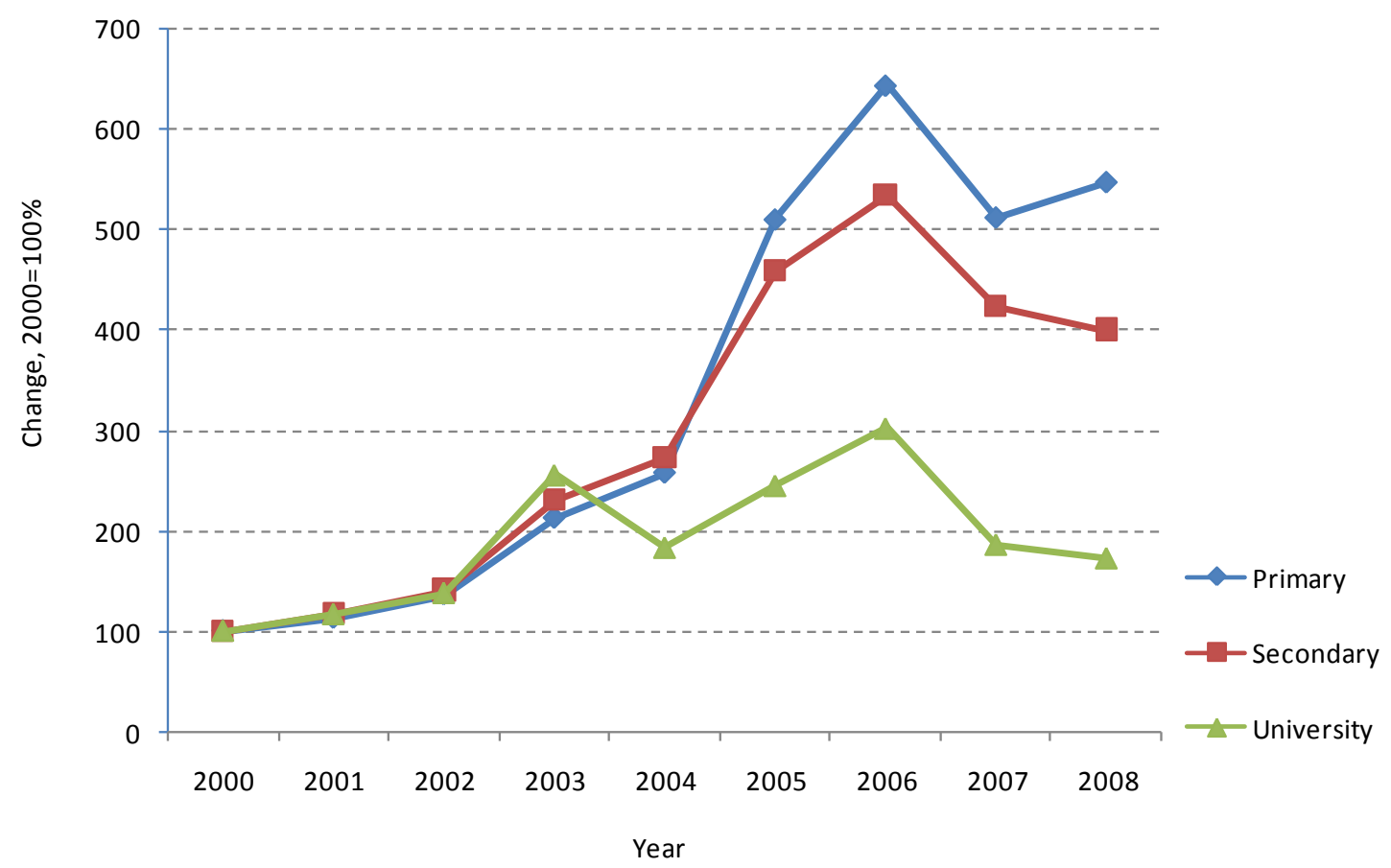

Figure 4. Changes in the level of education of emigrants between 2000 and 2008, $2000=100 \%$.

Source: EED. 


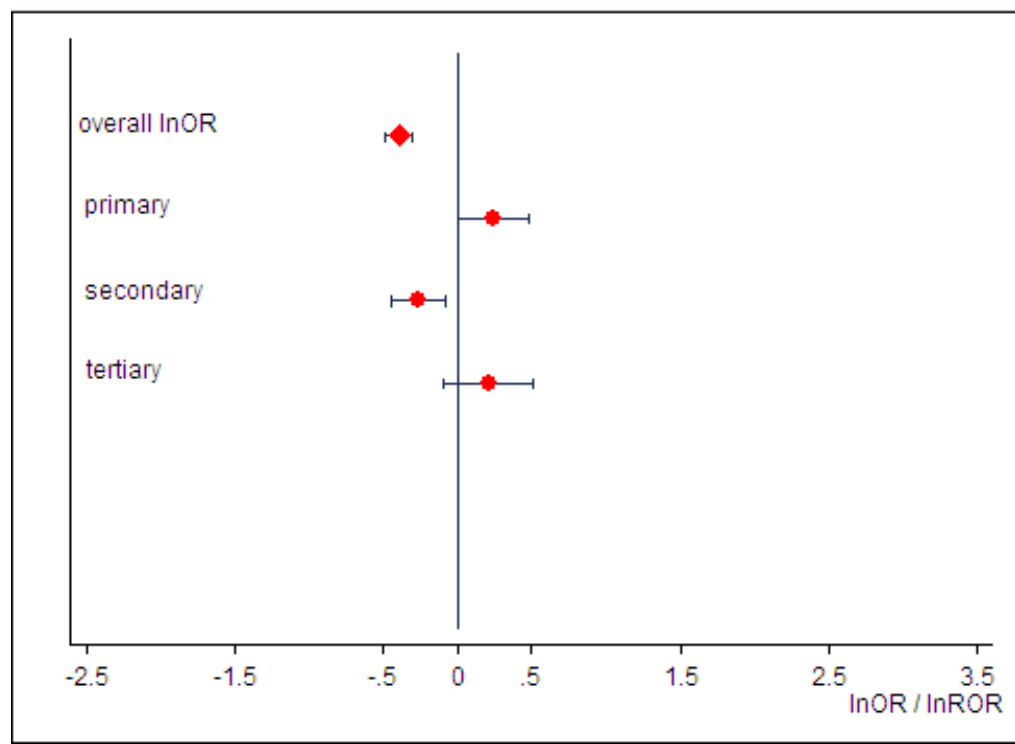

Figure 5. Forest plot for interaction of education with Russian ethnicity.

Source: EED. 
Table 1. Characteristics of Estonian emigrants and total population (\%).

\begin{tabular}{|c|c|c|c|c|c|}
\hline $\begin{array}{l}\text { Variable } \\
\text { group }\end{array}$ & Variable name & $\begin{array}{c}\text { Emigrants } \\
2000- \\
2004 \\
\end{array}$ & $\begin{array}{c}\text { Emigrants } \\
\text { 2004- } \\
2008 \\
\end{array}$ & $\begin{array}{c}\text { Emigrants } \\
2000- \\
2008 \\
\end{array}$ & $\begin{array}{c}\text { Total population } \\
2000\end{array}$ \\
\hline Dependent & Period of emigration & 21 & 79 & 100 & \\
\hline \multirow{19}{*}{$\begin{array}{l}\text { Personal } \\
\text { attributes }\end{array}$} & Education & & & & \\
\hline & Primary & 15 & 26 & 24 & 27 \\
\hline & Secondary & 51 & 50 & 50 & 55 \\
\hline & Tertiary & 10 & 5 & 6 & 15 \\
\hline & Unknown & 24 & 18 & 20 & 0 \\
\hline & Gender & & & & \\
\hline & Male & 40 & 45 & 44 & 44 \\
\hline & Female & 60 & 55 & 56 & 56 \\
\hline & Age & & & & \\
\hline & $20-29$ & 27 & 34 & 32 & 19 \\
\hline & $30-39$ & 29 & 29 & 29 & 18 \\
\hline & $40-49$ & 22 & 22 & 22 & 19 \\
\hline & $50-59$ & 11 & 10 & 10 & 16 \\
\hline & $60+$ & 12 & 4 & 6 & 28 \\
\hline & Ethnicity & & & & \\
\hline & Estonian & 52 & 72 & 67 & 66 \\
\hline & Russian & 18 & 13 & 14 & 27 \\
\hline & Other & 20 & 9 & 12 & 6 \\
\hline & Unknown & 10 & 6 & 7 & 1 \\
\hline \multirow{7}{*}{$\begin{array}{l}\text { Attributes of } \\
\text { origin }\end{array}$} & Origin & & & & \\
\hline & City & 67 & 56 & 58 & 61 \\
\hline & Hinterland & 15 & 17 & 17 & 14 \\
\hline & Periphery & 18 & 28 & 26 & 25 \\
\hline & Unemployment & & & & \\
\hline & Low & 68 & 68 & 68 & 65 \\
\hline & High & 32 & 32 & 32 & 35 \\
\hline \multirow{3}{*}{$\begin{array}{l}\text { Attributes of } \\
\text { destination } \\
\text { country }\end{array}$} & Destination country & & & & \\
\hline & Finland & 75 & 82 & 81 & \\
\hline & Other & 25 & 18 & 19 & \\
\hline
\end{tabular}

Sources: EED, Census 2000. 
Table 2. Changes in the propensity of emigrating from Estonia since joining the EU (odds ratios, 0 = emigrant 2000-2003, 1 = emigrant 2004-2008).

\begin{tabular}{|c|c|c|c|c|c|c|c|}
\hline \multirow{2}{*}{$\begin{array}{l}\begin{array}{l}\text { Variable } \\
\text { group }\end{array} \\
\begin{array}{l}\text { Personal } \\
\text { attributes }\end{array}\end{array}$} & Variable name & \multicolumn{2}{|l|}{$\begin{array}{l}\text { Model } 1 \\
\operatorname{Exp}(\mathrm{B})\end{array}$} & \multicolumn{2}{|l|}{$\begin{array}{l}\text { Model } 2 \\
\operatorname{Exp}(B)\end{array}$} & \multicolumn{2}{|c|}{$\begin{array}{l}\text { Model } 3 \\
\operatorname{Exp}(B)\end{array}$} \\
\hline & Education & 1734 & $* * *$ & 1709 & $* * *$ & 1714 & $* * *$ \\
\hline & Secondary & $\begin{array}{l}1.134 \\
1\end{array}$ & & 1 & & $\begin{array}{l}1.114 \\
1\end{array}$ & \\
\hline & Tertiary & 0.497 & $* * *$ & 0.598 & $* * *$ & 0.526 & $* * *$ \\
\hline & Unknown & 0.805 & $* * *$ & 0.876 & $* *$ & 0.867 & $* *$ \\
\hline & Gender & & & & & & \\
\hline & Male & & & 1 & & 1 & \\
\hline & Female & & & 0.946 & & 0.951 & \\
\hline & Age & & & & & & \\
\hline & $20-29$ & & & 1 & & 1 & \\
\hline & $30-39$ & & & 0.961 & & 0.975 & \\
\hline & $40-49$ & & & 0.987 & & 0.998 & \\
\hline & $50-59$ & & & 1.021 & & 1.032 & \\
\hline & $60+$ & & & 0.467 & $* * *$ & 0.493 & $* * *$ \\
\hline & Ethnicity & & & & & & \\
\hline & Estonian & & & 1 & & 1 & \\
\hline & Russian & & & 0.629 & $* * *$ & 0.585 & $* * *$ \\
\hline & Other & & & 0.427 & $* * *$ & 0.436 & $* * *$ \\
\hline & Unknown & & & 0.648 & $* * *$ & 0.693 & $* * *$ \\
\hline Attributes of & Origin & & & & & & \\
\hline origin & City & & & 1 & & 1 & \\
\hline & Hinterland & & & 1.114 & $* *$ & 1.115 & $* *$ \\
\hline & Periphery & & & 1.381 & $* * *$ & 1.381 & $* * *$ \\
\hline Attributes of & Destination country & & & & & & \\
\hline destination & Finland & & & 1.270 & 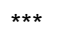 & 1.283 & $* * *$ \\
\hline country & Other & & & 1 & & 1 & \\
\hline Interaction & Education by Ethnicity $^{1}$ & & & & & & \\
\hline & Primary by Russian & & & & & 1.412 & $* *$ \\
\hline & Tertiary by Russian & & & & & 1.326 & $*$ \\
\hline & Unknown by Russian & & & & & 0.924 & \\
\hline & -2 Log likelihood & 19439.694 & & 18727.867 & & 18704.678 & \\
\hline
\end{tabular}

* Significant at $10 \%$ level; ** Significant at 5\% level; *** Significant at $1 \%$ level.

${ }^{1}$ Interactions between 'Education by Other (ethnicity)' and 'Education by Unknown (ethnicity)' are not shown.

Source: EED. 